\title{
LITERATURA ADICIONAL PARA LAS BRIOFITAS DE MEXICO
}

\author{
Claudio Delgadillo M.*
}

Desde la publicación de Literatura para las briofitas de México (Delgadillo M., C. 1969. Soc. Bot. Méx. Bol. 30: 127-135) han aparecido numerosas publicaciones sobre el mismo tema. Por otra parte, se han localizado citas bibliográficas previas a 1969 que no fueron incluidas en la primera lista. En vista del interés en la elahoración de una flora de musgos de México por Aaron J. Sharp y Frank 1). Bowers con la colaboración de otros investigadores (Bryologist 77: 106, 1974) parece adecuado revisar los antecedentes sobre estudios briológicos en México. La lista anexa puede contribuir a obtener datos sobre distribución, nomenclatura y taxonomía de las briofitas mexicanas. La lista de 1969 deberá consultarse para tener un panorama más completo de las briofitas de este país.

Anderson, L. E. 1971. Geographical relationships of the mosses of the Southern Appalachian Mountains. In P. (.. Holt led.) The distributional history of the biota of the Southern Appalachians. Part II. Flora. Research Division Vonograph 2. Virginia Polytechnic Institute and State University. Blacksburg, Va.

and R. H. Kanter. 197;. The moses of the Southern Blue Ridge Province and their phytogeographic relationsrip. Jour. Elisha Mitchell Sci. Soc. 89: 15.60 .

Avprews, A. I. 1922. The status of Gyroweisia in North America. Bryologist 25: 97.100 .

Aislix. C. F. 1875. New Hepaticae. Bull. Torrey Bot. Club 6: 4647.

BARTRAI. E. B. 1927. Some Arizona mosses not previously reported from the Inited States. Bryologist 30: $4.5-50$.

1933. The Templeton Crocker Expedition of the California Academy of Sciences, 1932. No. 8 Mosses of the Templeton Crocker Expedition collec. ted by John Thomas Howell and list of the mosses known from the Galapagos Islands and from Cocos lsland. Proc. Calif. Acad. Sci. 21: 75-86.

* Departamento de Botánica, Instituto de Biología, U.N.A.M., Ciudad Universitaria, Mixico 20, I). F.

Delgadillo-M C. 1975. Literatura adicional para las briofitas de México. Boletín de la Sociedad Botánica de México 35: 7-12. 
1946. New species and new combinations of Guatemalan mosses. Bryologist 49: 109-125.

1947. New species and new combinations of Guatemalan mosses II. Bryologist 50, 202-208.

Bescherelle, E. 1874. Bryologie exotique. Revue. Bryol. 1: 40:-43.

Bischler, H. 1964. Le genre Drepanolejeunea Steph. en Amérique Centrale et Méridionale. Revue Bryol. Lichénol. 33: 15-179.

— 1967. Le genre Drepanolejeunea Stepr. en Amérique Centrale et Méridionale. II. Revue Bryol. Lichénol. 35: 95-134.

1969. Le genre Leptolejeunea (Spruce) Steph. en Amérique. Nova Hedwigia 17: 265-350.

Bizot, M. et R. Portier de la Varde. 1952. Contribution à l'étude dul genre Erythrodontium. Revue Bryol. Lichénol. 21: 7-10.

Bowers, F. D. and A. J. Sharp. 1968. Conostomum pentastichum in Costa Rica and Mexico. Revue Bryol. Lichénol. 36: 243-244.

- - A. J. Sharp ayd H. Robinsox. 1973. Additional moses from Costa Rica and Mexico. Bryologist 76: 447-450.

Castle, H 1937. A revision of the genus Radula. Introduction and part I. Subgenus Chlororadula. Ann. Bryol. 9: 13-56.

1939. A revision of the genus. Raduk. Part II Subgenus Acroradula Ann. Bryol. 12: 21-47.

1959. A revision of the genus Rudulu. Part. II. Subgenus Acroradula. Sec. tion 3. Dichotomae. Jour. Hattori Bot. Lab. 21: 1.52.

1960. Radula pallens (Swartz) Dumortier, an unrecognized species of the leafy hepatics. Revue Bryol. Lichénol. 29: 10-25.

1963. A revision of the genus Rudulu. Part. II. Subgenus Acroradula. Section 6. Saccatae. Revue Bryol Lichénol. 32: 1-48.

1964. A revision of the genus Radula. Part. II. Subgenus Acroradula. Section 8. Acutilobae. Revue Bryol. Lichénol. 33: 185-210.

1964-1965. A revision of the genus Radula. Part. II. Subgenus Acroradula. Section 9. Densifoliae. Revue Bryol. Lichénol. 33: 328-398.

1966. A revision of the genus Radula. Part. II. Subgenus Acroradula. Section 10. Ampliatae. Revue Bryol. Lichénol. 34: 1-81.

Clark, L. 1953. Some hepaticae from the Calapagos. Cocos. and other Pacific coast isalnds. Proc. Calif. Acad. Sci. 4th. Ser. 27: 593-624.

Crosby. M. R. 1969. A revision of the tropical American moss genus Pilotrichum. Bryologist $72: 275-343$.

- 1970. A study of Groutiella apiculata and (;. mucronifolia. Bryologits 73: 607-611. 
Crum, H. A. 1969. Nomenclatural notes on North American mosses. Bryologist 72: 240-246.

1972. Mosses of unusual interest from Baja California. Madroño 21: 403404.

Davis, H. B. 1936. Life and work of Cyrus Guernsey Pringle. University of Vermont. Burlington.

Delgadillo M., C. 1969. Prytogeography of alpine mosses from Mexico. Preliminary studies. M S. thesis. The University of Tennessee, Knoxville. U.S.A.

- 1970. Two additions to the bryoflora of Mexico. Bryologist 73: 722-724.

1971. Phytogeographic studies on alpine mosses of Mexico. Bryologist 74: 331-346.

—_ AND D. H. VitT. 1971. New moss records from Mexico. Madroño 21: 99. 102.

Del Rosario, R. M. 1966. A new species of Asterella from Mexico. Rhodora 68: 470-473.

Duby, J. E. 1869. Choix de Cryptogames exotiques nouvelles ou mal connues. Mem. Soc. Phys. Hist. Nat. Genève 20: 1-14. + Plates. 2nd. pt.

Frye, T C. 1948. Atrichum oerstedianum. Bryologist 51: 242-246.

and M. W. Duckering. 1948. Atrichum polycurpum. Bryologist 5'1: 170174.

Geneeb, A. 1907. Les Splachnum luteum Montin et rubrum Montin, ontils été jamais observés en Mexique? Revue Bryol. 34: 71-73.

GRiris, D.. III. 1972. El musgo tropical Prionodon: Lotas taxonómicas y fitogeográficas. pp. 56-57 in "I Congreso Latinoamericano, V Mexicano de Botánica: Resúmenes". Sociedad liotánica de México.

Grol.te, R. 1962. Monographie der Lebermoosgattung Leptoscyphus Mitt. Nova Acta Leopol. 25: 1-143.

Hecewald, E. 1974. Beitrag zur Mooslora Perus. I. Bryomanginia saint-pierrei neu für Südamerika. Bryologist 77: 641-643.

Herzog, T. 1912. Musci. In Ross, H. Contributions à la flore du Mexique avec la collaboration de spécialistes. Mem. Soc. Cientif. "Antonio Alzate" 32 : 173-175.

Iwatsuki, Z. 1958. Correlation between the moss floras of Japan and of the southern Appalachians. Jour. Hattori Bot. Lah. 20: 304-352.

Kuwahar. Y. 1973. Further notes on the production of vegetative thallus structures by female involucres of Metzgeria and new species of Metzgeria. Bryologist $76: 566-571$. 
Lal, M. and M. K. Chandrasekhara Meuon. 1971. Physgomitrium delicalulum. new to the moss flora of India. Bryologist 74: 51-54.

Lenvevinorth, W. C. 1946. A preliminary study of the vegetation of the region between Cerro Tancítaro and the Río Tepalcatepec, Michoacán, Mexico. Amer. Midl. Nat. 36: 137-206.

Manuel, M. G. 1972. Additions to the moss flora of Mexico. Bryologist 75: 77. 79.

1973. Additions to the moss flora of Mexico. II. Bryologist 76:450-451.

1973. Studies in the Cryphaeaceae II. A review of the monotypic genus Dendropogonella Britt. Bryologist 76: 521-527.

1973. A second report for Drummondia pursellii Vitt $E$ Crum. Bryologist 76: 560 .

1974. A revised classification of the Leucodontaceae and a revision of the subfamily Alsioideae. Bryologist 77: 531-550.

Miller, N. G. and D. H. Vitt. 1970. Additional bryophytes from Sinkholes in Alpena County. Michigan, including Orthotrichum pallens new to eastern North America. Michigan Bot. 9: 87-94.

Norris, D. H. 1969. A small collection of bryophytes from Nayarit State. Mexico. Bryologist $72: 522-525$.

Nyнloy. E. 1971. Studies in the genus Atrichum P. Beauv. A short survey of the genus and the species. Lindbergia 1: 1-3.3.

Plerez García. B. 1970. Consideraciones sobre el ciclo biológico de Phaeoceros laevis carolinianus Proskauer. (Anthocerotaceae. Bryophyta). Tesis Profesional. Fac. Ciencias, L.N.A.M. México, D. F.

Proctor, V. W. 1972. The genus Kiella in North and South America: Distribution, Culture and Reproductive i-olation. Bryologist 75: 281-289.

Pirsel.1., R. A. 1971. Nomenclatural notes on American moses. Bryologi-t 74: $371-373$.

and W. D. ReEse. 1970. Phytogeographic affinities of the mosses of the Gulf Coastal Plain of the Lnited States and Mexico. Jour. Hattori Bot. Lab. 33: 115-152.

ReEse. W. D. 1960. Barbella pendula (Sull.) Fleisch.. a review of its distribution and comments on related species. Bryologist 69: 208-213.

1974. Syrrhopodon quintasii in the Americas. Bryologist 77: 212.213.

Roprason, H. 1970. A revision of the moss genus. Trichostomopsis. Phytologia 20: 184-191.

- and C. Delgadileo M. 1973. Neosharpiella, a new genus of musci from high elevations in Mexico and South America. Bryologist 76: 5:36-540. 
- WD F. D. Bowers. 1974. A new species of Oreoweisia from Mexico. Phytologia 29: 114-115.

ScHinper. W. P. 184:3. Dendropogon (Baumbart), eine Gattung der Laubmoose. Bot. Zeit. (Berlín) 1: 377-381.

Schorninerst, R. O. 1943. Phytogeographic studies of the mosses of Northern Florida. Amer. Midl. Natur. 29: 509-532.

Sil ARP, A. J. 1938. Tropical bryophytes in the southern Appalachians. Ann. Bryol. 11: 141-144.

1939. Taxonomic and ecological studies of Eastern Tennessee Bryophytes. Amer. Midl. Nat. 21: 267-354, i-vii.

Simti, G. L. 1969. Psilopilum mexicanum sp. nov. Phytologia 18: 401-402.

Sinfr, J. A. A 1 I) F. D. Bowers. 1974. Archidium, a moss genus new to Mexico. Bryologist 77: 639-64.1.

Stekle. W. C. 1938. Enthostodon wigginsii, a new species from southern Arizona. Bryologist 41: 36-40.

1945. Some North American mosses of doubtful antecedents. Revue Bryol. Lichénol. 15: 1-4.

1953. Preliminary report on the bryology of the Sefton-Standford Expedition to the Culf of California. 1952. Asa Gray Bull. N. S. 2: 93-95.

- and I). E. Chapuan. 1946. Mosses of El Salvador. Jour. Washington Acad. S(i. 36: $219 \cdot 225$.

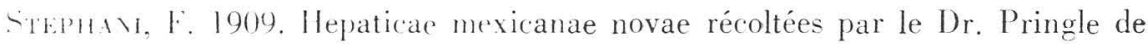
Bulington. Revue Bryol. 36: 138-140.

- 1912 Hepaticae In Ross, H. Contributions à la flore de Mexique avec la collaboration de pécialistes. Mem. Soc. Cientif. "Antonio Alzate" 32 : 172.173.

Tot1.:R, R. 1969 1970). The genus Frullania subgenus Frullania in Latin America. Lova Hedwigia 18: 397-555, pl. 1-38.

Siwails, L. F. Jr. 1970. The genus Porella in Latin America. Nova Hedwigia 19: $201-291$.

TıRrot, I. 1921. Reliquiar Delessertianae. Mousses du Mexique. Soc. Havraise d'Etudes Diverses. Le Havre. pp. 8-10.

Vitt. D. H. aуd H. A. C.ri v. 1968. A New species of Drummondia from Mexico. Bryologist $71: 117-119$.

1970. Groutiella tomentosa new to the Lnited States. Bryologist 73: 145149.

1972. A monograph of the genus Drummondiu. Canad. Jour. Bot. 50: 1191.1208. 
- 1973. A revisionary study of the genus Macrocoma. Rev. Bryol. Lichénol. 39: $205-220$.

Wagner, K. A. 1951. The Neckeraceae of North America. Univ. of Mich. Doctoral Dissertation Series Publ. No. 2665. Ann Arbor, Mich.

— 1952. Notes on the Neckeraceae. I. New names and new species. Bryologist 55: $143-147$.

Watson, S. 1876. Botanical Contributions. Proc. Amer. Acad. Arts E Sci. n.s. 3: 105-148.

__ 1883. Contributions to American botany. I. List of plants from soutliwes. tern Texas and northern Nexico, collected chiefly by Dr. E. Palmer in 1879-80. Proc. Amer. Acad. Arts \& Sci. n.s. 10: 96-191.

Welch, W. 1967. Hookeriaceae species and distribution in North and Central America and West Indies. Proc. Ind. Acad. Sci. 77: 351-356.

— 1971. Lepidopilum subtortifolium Bartr. in North America: Mexico. Bryologist 74: 212-213.

1972. Hookeriaceae: North America and West Indies, additions and appendix. Bryologist 75: 456-461.

Willinus, R. S. 1912. The genus Clastobryum Doz. and Molk. in America. Bryologist 15: 31 .

—_ 19]3. The genus Husnotiella Cardot. Bryologist 16: 25.

1919. The genus Desmatodon in North America. Bull. Torrey Bot. Club 46: $207-220+$ pl. 11.

1922. Brachymenium condensatum sp. nov. Bryologist 26:2-3.

Zivaer, R. H. 1969. Revision of the genus Leptodontium (Musci) in the Vew World. Ph. D. dissertation. Duke University.

1972. Revision of the genus Leptodentium (Musci) in the New Worlt. Bryologist $75: 213-280$.

1973. El género Amphidium antes desconocido en México. Misc. Bryol. Lichénol. 6: 96-97. 